\title{
Colorectal Cancer cM1a TNM Finding v8
}

National Cancer Institute

\section{Source}

National Cancer Institute. Colorectal Cancer CM1a TNM Finding v8. NCI Thesaurus. Code C134141.

Colorectal cancer with metastasis to one site or organ without peritoneal metastasis. (from AJCC 8th Ed.) 